\title{
Women's health and night shift work: Potential targets for future strategies in breast cancer (Review)
}

\author{
GIUSI BRIGUGLIO $^{1 *}$, CHIARA COSTA $^{2 *}$, MICHELE TEODORO $^{1}$, FEDERICA GIAMBÒ ${ }^{1}$, \\ SEBASTIANO ITALIA $^{1}$ and CONCETTINA FENGA ${ }^{1}$ \\ ${ }^{1}$ Department of Biomedical and Dental Sciences and Morphofunctional Imaging, Occupational Medicine Section; \\ ${ }^{2}$ Department of Clinical and Experimental Medicine, University of Messina, I-98125 Messina, Italy
}

Received July 2,2021; Accepted August 12, 2021

DOI: 10.3892/br.2021.1474

\begin{abstract}
Breast cancer is the leading cause of cancer-associated amongst women worldwide. Several studies have shown that individual, environmental and occupational factors can serve an important role in the onset of breast cancer; although the majority of studies have demonstrated this association, and several studies have investigated the biological pathways, it is impossible to describe with certainty the causal relationship that involve circadian rhythm disruption and melatonin dysregulation with the oncogenic processes. Over the years, due to the introduction of more effective screening tools, an increase in the incidence of breast cancer as well as a decrease in the age at diagnosis has been witnessed. Subsequently, an increasing number of individuals have obtained care at a younger age, which has meant that after surgery and chemotherapy, these workers have had to return to work. In light of these paradigmatic changes, the aim of the present review was to identify potential targets for future organisational strategies that should be adopted in the workplace by occupational physicians, both for prevention and for the return-to-work process of working women who have suffered from breast cancer.
\end{abstract}

\section{Contents}

1. Introduction

2. Literature search

3. Mechanistic pathways

4. Risk assessment and prevention strategies

5. Conclusions

Correspondence to: Dr Michele Teodoro, Department of Biomedical and Dental Sciences and Morphofunctional Imaging, Occupational Medicine Section, University of Messina, Via Consolare Valeria 1, I-98125 Messina, Italy

E-mail: michele.teodoro@unime.it

*Contributed equally

Key words: breast cancer, night shift work, occupational exposure, risk assessment, occupational physician

\section{Introduction}

Breast cancer (BC) is the leading cause of cancer-associated amongst women worldwide. Considering the most updated data on BC from 2020, 2.261.419 new cases of BC were registered worldwide (accounting for $24.5 \%$ of all tumours in women). Of these, 531,086 cases (25.8\%) in Europe were detected, with 55,133 new diagnoses (28.1\%) in Italy (1).

$\mathrm{BC}$ is a multifactorial disease; however, the different risk factors established for pathological development do not fully explain the aetiology of the disease. The results of several studies showed that individual, environmental and occupational factors serve a critical role in the onset of this pathology (2-6). In women, the most common individual risk factors causing hereditary $\mathrm{BC}$ are genetic mutations involving the BRCA1 or BRCA2 genes. However, there are also less common inherited mutations in other genes, including ATM, TP53, CHEK2, PTEN, CDH1, STK11 and PALB2 (7). Lifestyle is an important risk factor, with lack of physical activity, excessive consumption of alcohol, a high body mass index (BMI), a high-fat diet and smoking all increasing the risk (2,8-11). Ethnicity, age and socio-economic status can influence the risk of developing $\mathrm{BC}$. White women exhibit the highest incidence of $\mathrm{BC}$, followed by Black, Asian and Hispanic women. This could be explained by racial and socioeconomic barriers to early detection and screening, and unequal access to treatment, as well as differences in lifestyles (12-16). Other individual factors are attributable to procreative aspects, such as the onset of menarche and menopause, as well as the age of first pregnancy with breastfeeding (17-19). Last but not least, a familiar BC and/or general predisposition to cancer may represent important risk factors $(17,18)$, such as chronic fatigue, sleep disturbance and depression (20-22). Several studies have investigated the gene-environment interactions showing that $\mathrm{BC}$ risk is related to the common susceptibility variants, which can be altered by environmental factors, such as industrial air pollutants, soil or water contamination due to heavy metals and genotoxic agents, active or passive tobacco smoke (3,10,23-34). Finally, several occupational factors can expose workers to a higher risk of $\mathrm{BC}$ due to toxic compounds or exposure to ionising radiation, rotating night shifts or higher-status occupations (35-42). 
This last association between $\mathrm{BC}$ and occupational factors is a topical issue, since it is estimated that exposure to occupational hazards causes up to $8 \%$ of cancers $(37,43,44)$.

According to data from the seventh European Working Conditions Survey in 2020, 13 and $15 \%$ of female workers, in Italy (ITA) and European Union (EU) respectively, declared exposure to chemical products or substances for at least $25 \%$ of the time in the workplace. Moreover, $10 \%$ (ITA) and $14 \%$ (EU) of women stated they worked $\geq 1$ time a month at night, whereas $18 \%$ (ITA) and $21 \%$ (EU) declared to perform work shifts (45).

Occupational exposure to rotating or night shifts could lead to the onset of tumours such as BC $(46,47)$. In fact, in 2019 , the International Agency for Research on Cancer (IARC) published a monograph that considered the relationship between night shift work and carcinogenesis. Based on both epidemiological and experimental scientific contributions on animals, the IARC Working Group defined night shift work, which causes an alteration of circadian rhythms, as a probable human carcinogen, with classification $2 \mathrm{~A}$ (limited scientific evidence in humans, but sufficient evidence in animals) (48).

Although the results of the latest studies are controversial, the main pathogenetic hypothesis is based on the impact that night shift work and night light exposure could have on the rhythmicity of the circadian biological functions (49,50). These alterations result in disturbance of circadian rhythms, reduction of melatonin production and sleep perturbation, affecting several metabolic and physiological processes, including hormone synthesis and cell cycle progression (51-54).

Amongst the several mechanisms proposed to determine the effects of artificial light at night on $\mathrm{BC}$, the majority seem to highlight the importance of inhibition of melatonin secretion during the night due to sleep deprivation, resulting in chronodisruption (55). In women performing shift or night work, melatonin secretion is inhibited by light, resulting in an increase in estrogen, since it has a significant anti-estrogenic activity $(54,56)$.

This multifaceted hypothesis may explain why night workers may have a greater risk of developing BC compared to the general population $(42,52,55,57)$ and why work organisations should implement a strategic procedure to prevent $\mathrm{BC}$. Under these premises and also in light of the new evidence, this review aims to provide an overview of the most relevant risk factors, providing recommendations to fill gaps in risk assessment and suggest novel organisational strategies that occupational physicians should adopt in the workplace, both for the prevention and return-to-work process of female workers affected by BC.

\section{Literature search}

The review was performed by searching PubMed, Scopus and Web of Science databases. The inclusion criteria were: Full-text studies, published in English, published between 2015-2021, and studies associating BC risk with occupational factors, particularly shift and night work. Certain studies, although methodologically sound, were excluded as they were considered irrelevant to the purpose of the study. Most articles were found using the terms: 'breast cancer' AND 'night shift' OR 'breast cancer' AND 'night shift work' OR 'breast cancer'
AND 'occupational exposure' OR 'breast cancer' AND 'occupational risk'. No restrictions were applied to the country of origin or ethnicity of the patients recruited. Furthermore, based on titles and abstracts, the relevance of the topic and admissibility of all the retrieved publications were further assessed. Finally, further relevant studies were identified through manual screening of the selected articles' reference lists and recently published reviews.

\section{Mechanistic pathways}

Shift work and melatonin secretion. Although the literature is controversial, as summarized in Table I, numerous studies have suggested that shift work and the night shift may represent one of the main occupational risks associated with BC $(35,36,52,58)$.

Cordina-Duverger et al (59) analysed five case-controlled studies (Australia, Canada, France, Germany and Spain) by pooling the data into a single standardised dataset, demonstrating that night work amplified the risk of BC in women in premenopause, especially in those with a high frequency of night work, measured as the number of nights per week, and a long period of exposure. Amongst premenopausal women, the risk of $\mathrm{BC}$ was higher in recent night workers [odds ratio $(\mathrm{OR})=1.41 ; 95 \%$ confidence interval $(\mathrm{CI}), 1.06-1.88]$ than in those who had stopped night work more than 2 years earlier (59). Similarly, women who worked at night showed an increased risk of developing $\mathrm{BC}$ when compared to women who never worked nights in Mexico (OR=8.58; 95\% CI, 2.19-33.8) (49), as well as in Poland (OR=2.61; 95\% CI, 1.94-3.53) (46). However, there was only a slight increase in higher BC risk amongst night shift workers in the Sister Study, with a cohort of 50,884 women who had a sister with breast tumour, but were BC-free themselves (60). Moreover, in a study conducted in Canada, Levin's equation was applied to assess attributable population fractions (PAFs) amongst women who worked night or rotating shifts in 1961-2000. The PAFs varied from 2.0-5.2, and 38\% of overall incident BC cases in 2011 were detected in women who worked in health-related occupational environments (61). Nevertheless, this increased risk was observed in two prospective cohorts $(5,971$ in the Nurses' Health Study and 3,570 in the Nurses' Health Study 2, performed in USA), which showed an association between a high risk of BC and long-term night shift work (35). Conversely, in a study conducted on Korean women (62), and another study based on the Generations Study cohort (63) demonstrated the lack of association between night shift work and an increased risk of developing BC.

The causal links between night work and $\mathrm{BC}$ have yet to be established, although a plausible biological mechanism could be related to night light-related disruption of the circadian rhythm. The inhibition of night melatonin secretion along with sleep deprivation and chronodisruption is suggested to be a crucial mechanism by which artificial light at night could contribute to BC development (55).

However, even with regard to this proposed mechanism, the studies have shown contested results; a case-controlled study performed in Vancouver found no association between nocturnal artificial light and BC (64); whereas a case-controlled study performed in China (65) and a population-based case-controlled study in Spain (66) both 


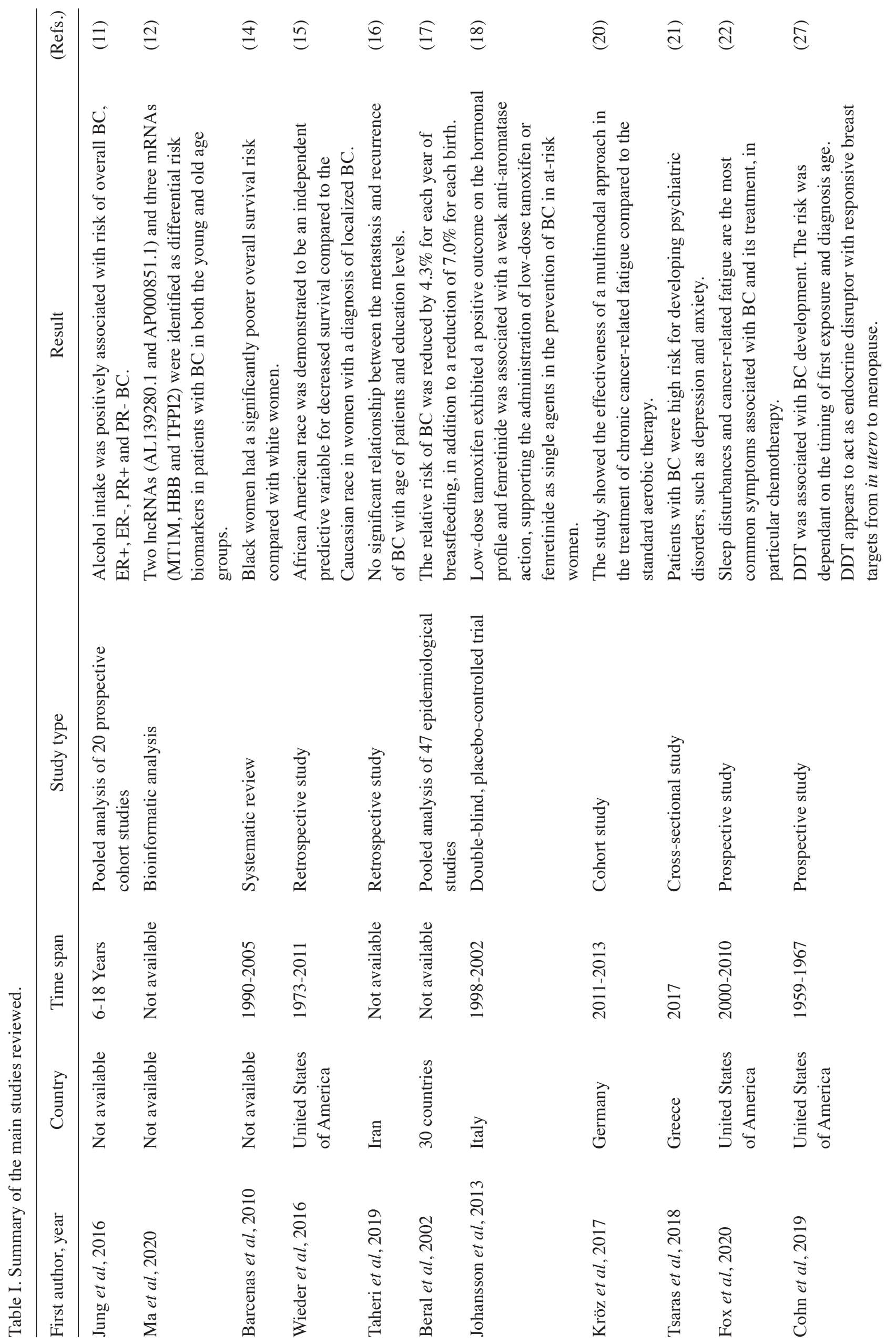




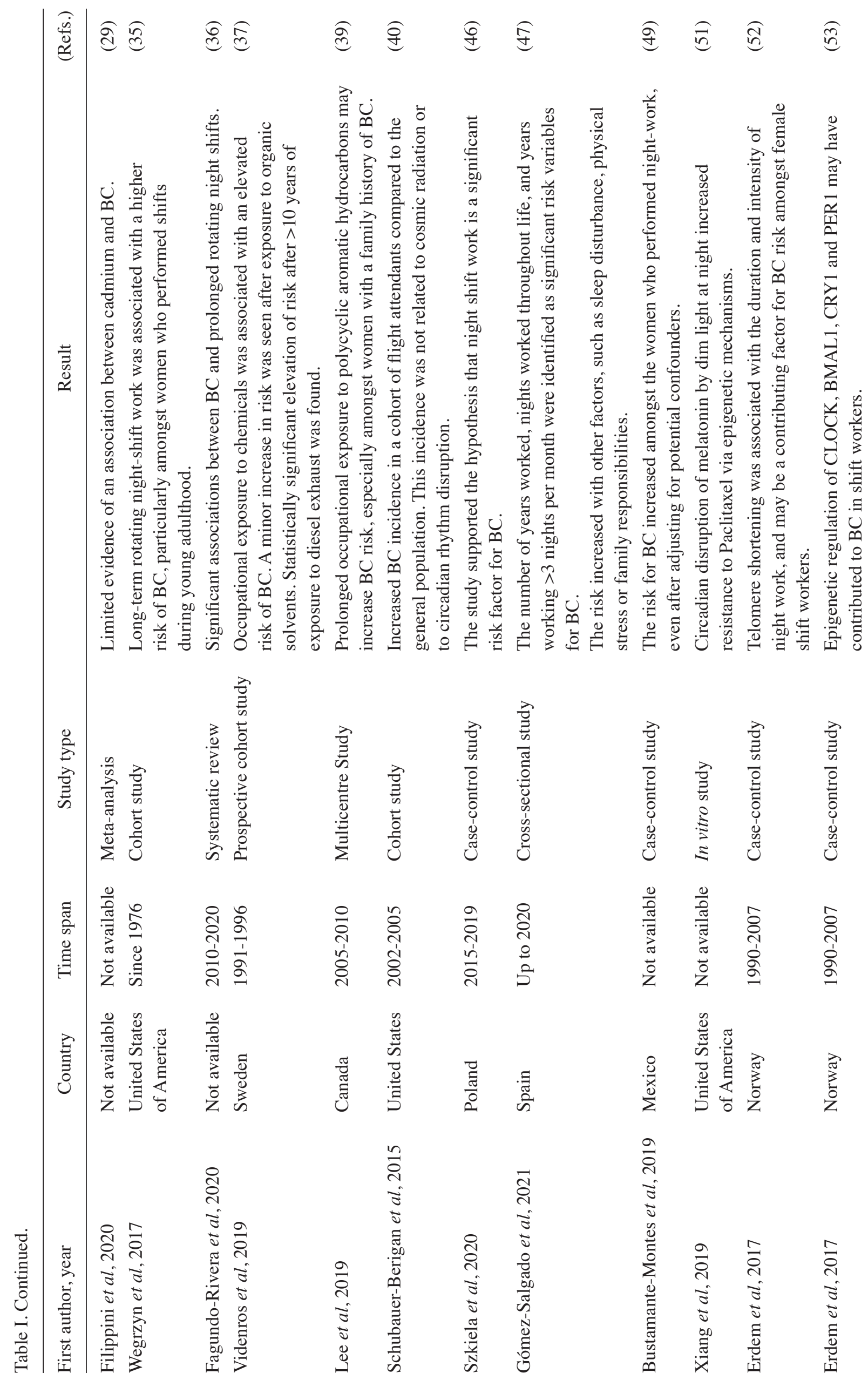




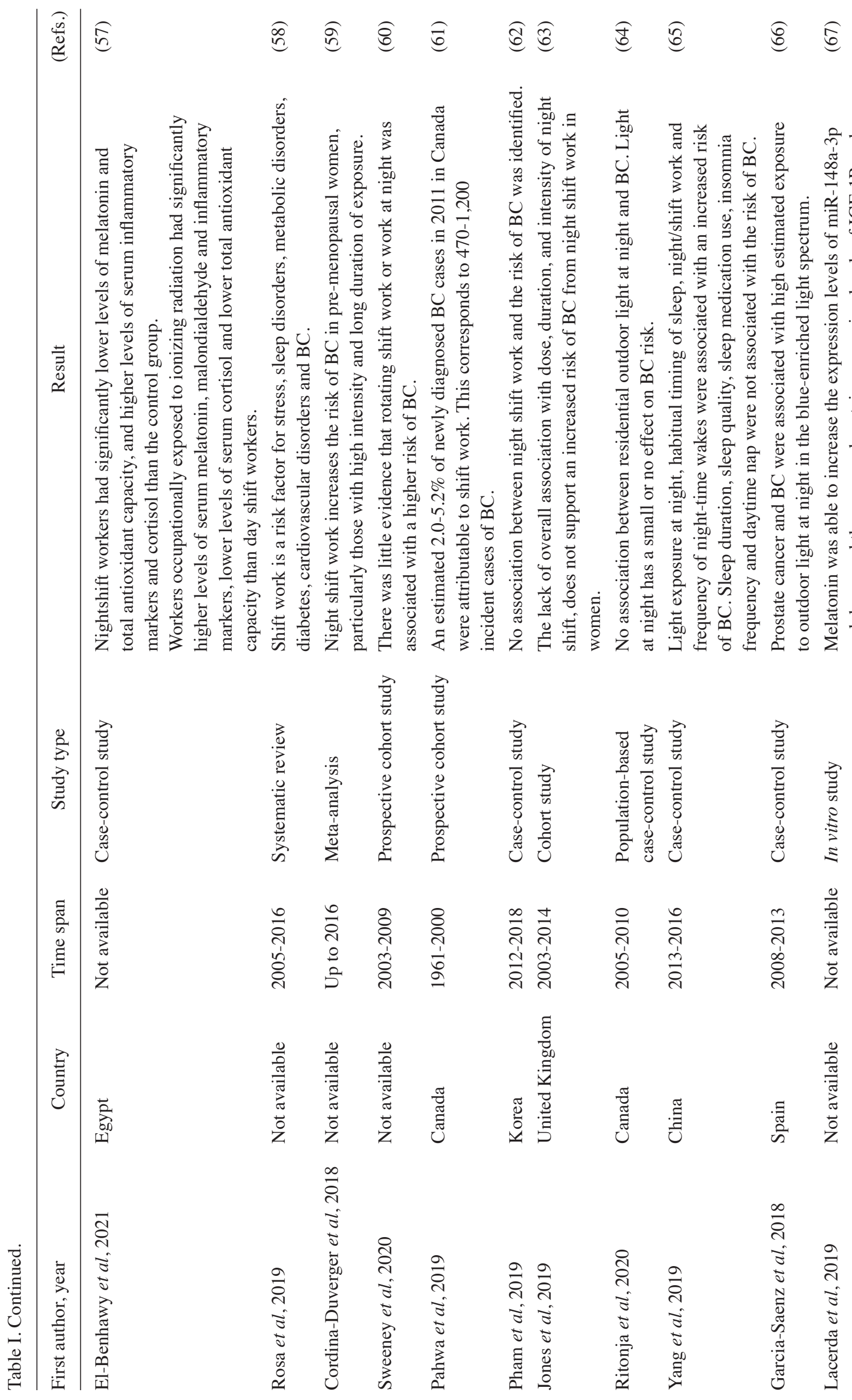




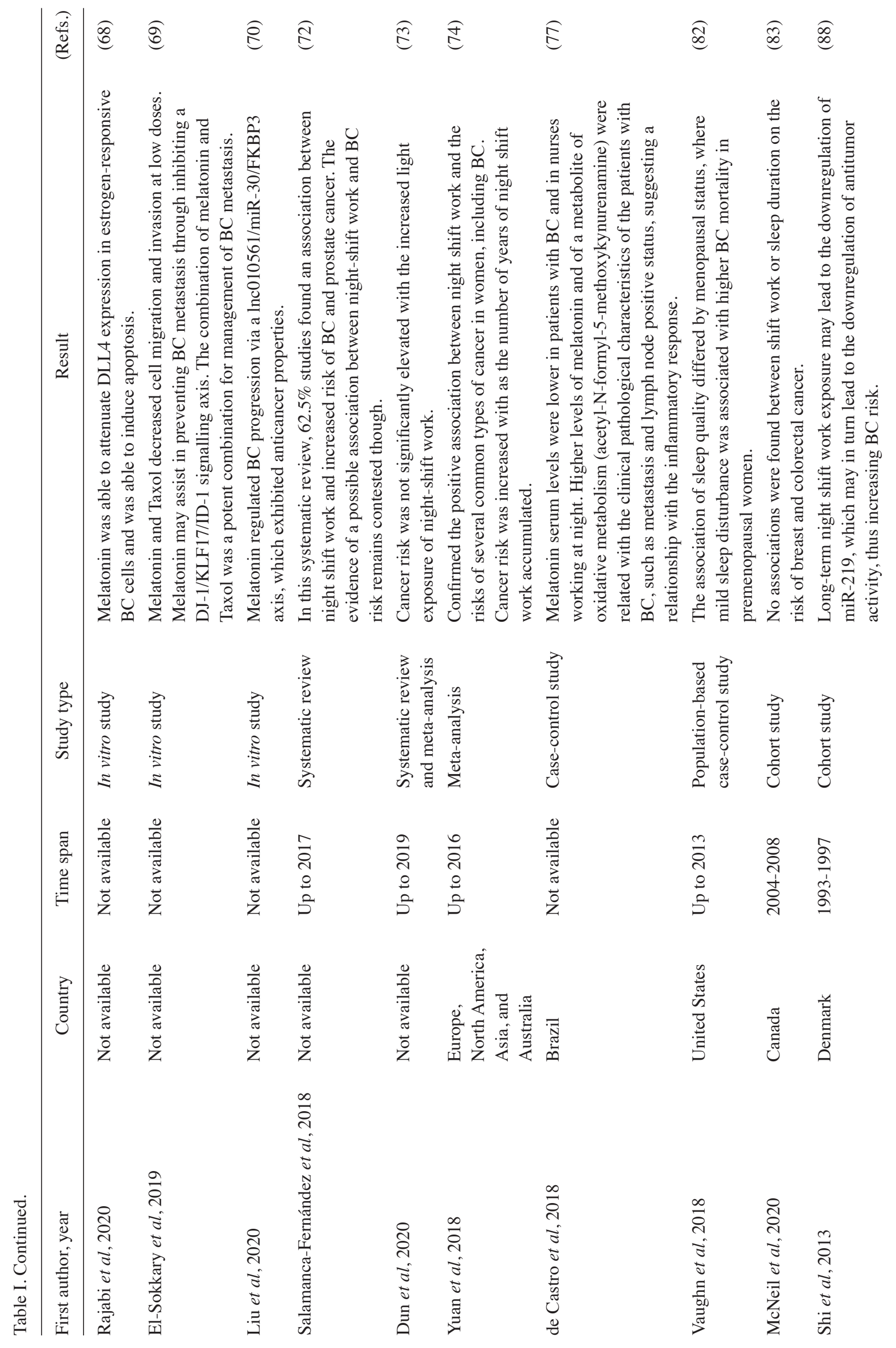




\section{Risk assessment and prevention strategies}

In work schedules characterized by night shifts, the occupational physicians can play a key role both in risk assessment and in prevention strategies. In particular, when workers susceptible to $\mathrm{BC}$ are employed, healthcare professionals can provide strategic contributions for primary prevention, health promotion and return to work. Primary prevention has different targets, such as adequately assessing the suitability for shift work, organising shifts according to ergonomic criteria, and adopting adequate compensatory measures to avoid significant disturbances in circadian rhythms, accumulation of sleep loss and conflicts in social life. Although certain pathologies can constitute a handicap for rotating or night work, shift work cannot and must not be a discriminatory criterion for selecting workers. Particularly, for female workers, more stressful living conditions can arise in relation to time pressures caused by the conflict between irregular working hours and habitual domestic commitments, especially for those women who are married and with children. Conversely, it may be the specific family conditions and/or economic needs that force several women to accept shift or night work. However, it is clear that there is no optimal or best shift pattern, so each shift scheme must be planned and adopted, taking into account the specific working conditions, the peculiar requirements of the tasks, and the particular individual and social characteristics of the workers. The occupational physician should evaluate individual health conditions, which could be related to or aggravated by shift work, to exempt workers from shift work or at least from the night shifts. It is also necessary that helpful information and suggestions should be given to workers on how to best cope with shift and night work, particularly concerning sleep, diet, stress control and good physical health.

Regarding the organization of work schedules, it is advisable to reduce night work by adopting rapid rotation schemes to limit the number of consecutive night shifts as much as possible, reducing the interference on circadian rhythms and sleep. In fact, it is suggested to prefer the rotation of shifts in 'phase delay' (Morning/Afternoon/Night), which supports the natural biological circadian rhythms, interspersed by at least $11 \mathrm{~h}$ intervals between one shift and the next, in order to allow improved recovery from any sleep loss and fatigue.

The occupational physician can also implement health promotion programs targeting the primary individual risk factors, promoting healthy lifestyle behaviours, for example supporting the introduction of a Mediterranean diet, that has been shown to be associated with a lower risk of $\mathrm{BC}$ incidence in women $(94,95)$. The typical Mediterranean diet nutrients have shown a positive influence on the expression of inflammatory biomarkers, oxidative stress, DNA damage and genetic modifications, all aspects that can affect BC outcomes $(96,97)$. Moreover, lifestyle modifications can positively impact BC survival, whose lower health-related quality of life negatively affects treatment compliance and disease outcomes (98).

Occupational physicians should encourage $\mathrm{BC}$ screening programs in female workers at risk of $\mathrm{BC}$. It is well established that inclusion into mammography screening programs can result in earlier detection, showing a decrease in the rate of mastectomies, favouring breast conservation surgery. Therefore, BC screening programs are associated with re-employment; in fact, 
showed that there was an increased risk of $\mathrm{BC}$ associated with exposure to night light, in particular, with external light in the blue spectrum.

To better understand the association between night work, the disruption of the circadian rhythm and the risk of $\mathrm{BC}$, several studies investigated the role of the genes involved in the circadian pathway and melatonin regulation (51,67-71). However, both the relationship between circadian rhythm and genetic expression/modification and specific markers continues to be debated (50,72-75).

Moreover, melatonin is also a powerful antioxidant, due to its capacity to scavenge free radicals and stimulate antioxidative enzymes (76). Lower levels of melatonin were observed in patients with BC, suggesting that working at night modifies the circulating levels of biomarkers associated with inflammation and redox reactions $(57,77)$.

Neuroendocrine disruption. In women employed in shift or night work, melatonin secretion, which has anti-estrogenic activity, is inhibited by light, resulting in a rise in estrogen levels (56). It is well known that early menarche, late menopause and no pregnancies, all factors linked to sex hormones exposure, are associated with an increased risk of BC (78). Sleep deprivation, resulting in shift work disorder, characterised by excessive sleepiness and sleep disturbances (79), has a strong influence on the neuro-immune-endocrine axis, which can affect cell proliferation and immune responses, including cytokine production (80) and some plasma metabolites, that may play an essential role in the circadian system (81). In particular, Daly et al (8) described a $16 \%$ increase in the incidence of BC in women aged 25-49 since 1990s, which may be at least partly attributed to more improved screening programs and detection methods, as well as changing lifestyles, highlighting the role of the endocrine factors in the onset of $\mathrm{BC}$. In fact, younger women ( $<40$ years) seem to be affected by more aggressive phenotypes of $\mathrm{BC}$, resulting in a higher mortality rate. Moreover, young women were more likely to exhibit advanced disease stage tumours (larger size, lymph node involvement, poorly differentiated). Still, women aged $<40$ years seem to have a higher frequency of familiar history of $\mathrm{BC}$, with a higher frequency of pathogenic mutations in the BC genes (BRCA1, BRCA2, TP53 and PALB2) compared with women with $\mathrm{BC}$ that develops after the age of 40 , thus mutation penetrance appears higher in younger patients (8).

Regarding the relationship between poor sleep quality and $\mathrm{BC}$, it is impossible to give a straightforward interpretation. In general, sleep disturbances are likely to be associated with aggressive subtypes of BC, as demonstrated by the Western New York Exposures and Breast Cancer study (82), conducted on a sample of 1,122 subjects with incident BC. This investigation also showed that sleep quality, well-known to be influenced by occupational features (42), is also linked to the state of menopause. However, no association was found between $\mathrm{BC}$ risk and sleep duration, sleep quality, use of sleep medication, frequency of insomnia and daytime napping in a case-controlled study conducted in China (65). This research showed that night shift work and frequency of nocturnal awakenings were associated with an increased risk of BC independently from menopausal status and tumour estrogen receptor status. Conversely, research on 21,804 participants from Alberta's Tomorrow project evaluated the primary effects of shift work and sleep duration on cancer incidence, and found no association between shift work or sleep duration and $\mathrm{BC}$ risk (83).

Disruption of circadian genes. Changes in the expression of circadian genes can be attributed to genetic or epigenetic mechanisms. Certain genes [Brain and Muscle ARNT-Like 1 (Bmal1), Period Circadian Regulator (Per)1 and Per2] have been hypothesized to act as tumour suppressors $(84,85)$. Primary epigenetic controls are represented by DNA methylation and the modifications of histones (86). Altered expression of genes associated with the circadian rhythm is associated with atypical cell proliferation, impairment of DNA repair systems and apoptosis, the response to DNA damage, and an increase in drug resistance in human cancer cells (85). A previous study observed that mice with a shorter circadian cycle showed hypermethylation in the promoters of cryptochrome circadian regulator 1 (Cry1) and Per2 genes and hypomethylation in the Circadian Locomotor Output Cycles Kaput (CLOCK) promoter (87).

Several studies have demonstrated that lifestyle and circadian disruption are associated with changes in microRNA expression, such as miR-127, miR-146b and miR-219. These altered miRNA profiles may then lead to epigenetic modifications, supporting the hypothesis that long-term night shift work may increase $\mathrm{BC}$ risk $(88,89)$.

A study conducted on Korean women investigated 22 polymorphisms in 11 genes in 941 cases of BC and 959 controls. In the analysis of single nucleotide polymorphisms, a correlation between night shift work and BC was found; specifically, night shift exposure increased the risk of BC in women carrying the heterozygous genotype of CRY2 rs2292912 or carrying at least one minor allele of RORA rs1482057 (90). Epigenetic changes in 5-methyl cytosine in five circadian genes, BMAL1, CLOCK, CRY1, PER1 and PER2, were also analysed in a population of night shift female nurses (278 BC cases, 280 controls). The authors suggested that epigenetic alteration of CLOCK, BMAL1, CRY1 and PER1 may contribute to BC in night shift workers. An Italian study found that night shifts were associated with ESR1, TP53 and BRCA1 hypomethylation in female nurses. IFurther analysis showed that these night shift-associated markers could be of potential interest in the study of cellular ageing, genomic variability and cancer development (91). In another case-controlled study amongst Norwegian nurses, intensity and length of night work were associated with telomere shortening, which may contribute to an increased risk of BC amongst women working in shifts (52).

Bracci et al (92) evaluated alterations in BRCA expression in shift workers, finding lower levels of BRCA1 and BRCA2 in shift workers than in day workers, suggesting a potential role associated with a higher risk of BC (92).

In a murine model of spontaneous mammary carcinogenesis, authors noticed that mixed-background mice (B6*FVB PyMT:Luc2) developed BC within 10-12 weeks of age, and demonstrated that the circadian rhythm disruption considerably enhanced cancer-cell dissemination and pulmonary metastasis, and affected the immunosuppressive response showing the role of circadian dysregulation on breast tumour progression (93). 

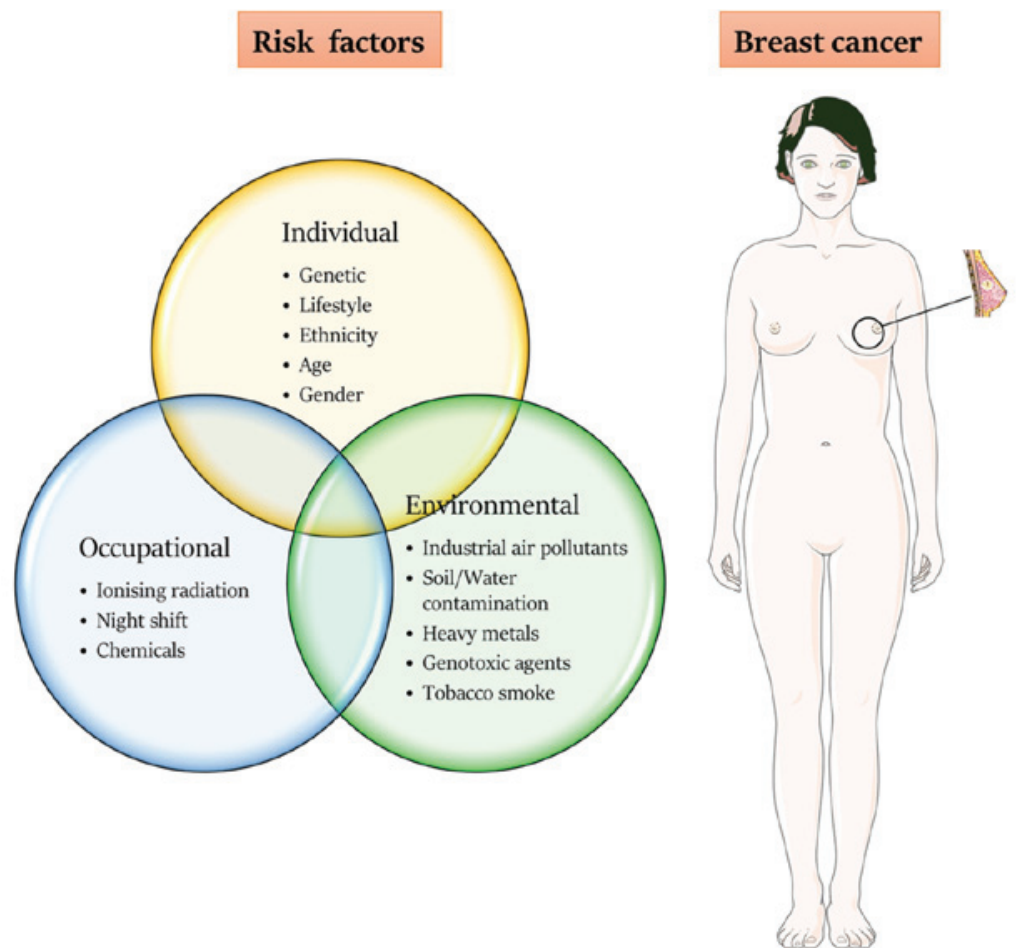

\section{Occupational physicians}

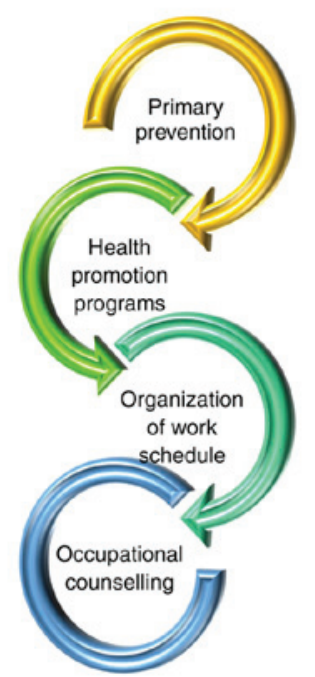

Figure 1. Interaction between individual, environmental and occupational risk factors in the development of breast cancer, as well as the role of the occupational physician.

an early diagnosis is frequently followed by a more efficient recovery and improved ability to work. After BC curative treatment, the assessment of a patient's ability to return to work should consider the following: Clinical outcomes, lifestyle and occupational variables. After the sick leave period, employer support to simplify the employee rehabilitation has been associated with a positive return to work experience. A rehabilitation program that combines occupational counselling, physical workout programs and physiotherapy during chemotherapy resulted in an increased return rate to work, improved quality of life and better ability to work (99). In this setting, the role of occupational physicians is crucial in informing workers on the benefits of rehabilitation plans, healthy lifestyles and assistances guaranteed by the law. A virtuous occupational physician should collaborate with the employer to adjust individual risk assessment and optimize tailored calibration of work tasks (Fig. 1).

\section{Conclusions}

The current review focused on the contribution of the occupational physician to the prevention and management of $\mathrm{BC}$ in the workplace, with a brief overview of the main individual, environmental and occupational risk factors associated with BC, which may have synergistic effects towards the susceptibility, development and progression of $\mathrm{BC}$.

The overall examination of the reviewed contributions does not allow to exclude that exposure to shift and night work is related to an increased risk of developing $\mathrm{BC}$; moreover, it leads to the hypothesis that this relationship is supported by both a theoretical background and possible pathogenetic mechanisms.

Though further studies are needed to establish a causal link, this review suggests introduction of a novel approach to management, including screening tools in the workplace, especially targeting those workers with greater exposure to shift or night work.

In this context, the role of the occupational physician is crucial in primary prevention, health promotion and in the return to work process. In particular, this return to work phase should take into consideration a multidisciplinary approach, involving employers adopting working features tailored on the specific worker's conditions.

\section{Acknowledgements}

Not applicable.

\section{Funding}

No funding was received.

\section{Availability of data and materials}

Not applicable.

\section{Authors' contributions}

CC, CF and FG conceived the subject of the review. GB, SI and MT contributed to writing the manuscript. All authors have read and approved the final manuscript. Data authentication is not applicable.

\section{Ethics approval and consent to participate}

Not applicable. 


\section{Patient consent for publication}

Not applicable.

\section{Competing interests}

The authors declare that they have no competing interests.

\section{References}

1. World Health Organization International Agency for Research on Cancer (IARC): GLOBOCAN 2020, 2020.

2. Kispert $\mathrm{S}$ and $\mathrm{McH}$ owat J: Recent insights into cigarette smoking as a lifestyle risk factor for breast cancer. Breast Cancer (Dove Med Press 9: 127-132, 2017.

3. Costa C, Teodoro M, Rugolo CA, Alibrando C, Giambò F, Briguglio $\mathrm{G}$ and Fenga $\mathrm{C}$ : MicroRNAs alteration as early biomarkers for cancer and neurodegenerative diseases: New challenges in pesticides exposure. Toxicol Rep 7: 759-767, 2020.

4. Kumar S, Sharma A and Kshetrimayum C: Environmental and occupational exposure and female reproductive dysfunction. Indian J Med Res 150: 532-545, 2019.

5. Fenga C: Occupational exposure and risk of breast cancer (Review). Biomed Rep 4: 282-292, 2016.

6. Golubnitschaja O, Debald M, Yeghiazaryan K, Kuhn W, Pešta M, Costigliola V and Grech G: Breast cancer epidemic in the early twenty-first century: Evaluation of risk factors, cumulative questionnaires and recommendations for preventive measures. Tumor Biol 37: 12941-12957, 2016.

7. Feng Y, Spezia M, Huang S, Yuan C, Zeng Z, Zhang L, Ji X, Liu W, Huang B, Luo W, et al: Breast cancer development and progression: Risk factors, cancer stem cells, signaling pathways, genomics, and molecular pathogenesis. Genes Dis 5: 77-106, 2018.

8. Daly AA, Rolph R, Cutress RI and Copson ER: A review of modifiable risk factors in young women for the prevention of breast cancer. Breast Cancer (Dove Med Press) 13: 241-257, 2021

9. Siegel RL, Miller KD and Jemal A: Cancer statistics, 2017. CA Cancer J Clin 67: 7-30, 2017.

10. Rudolph A, Chang-Claude J and Schmidt MK: Gene-environment interaction and risk of breast cancer. Br J Cancer 114: 125-133, 2016.

11. Jung S, Wang M, Anderson K, Baglietto L, Bergkvist L, Bernstein L, van den Brandt PA, Brinton L, Buring JE, Eliassen $\mathrm{AH}$, et al: Alcohol consumption and breast cancer risk by estrogen receptor status: In a pooled analysis of 20 studies. Int J Epidemiol 45: 916-928, 2016.

12. Ma X, Liu C, Xu X, Liu L, Gao C, Zhuang J, Li H, Feng F, Zhou C, Liu Z, et al: Biomarker expression analysis in different age groups revealed age was a risk factor for breast cancer. J Cell Physiol 235: 4268-4278, 2020.

13. Yedjou CG, Sims JN, Miele L, Noubissi F, Lowe L, Fonseca DD, Alo RA, Payton M and Tchounwou PB: Health and racial disparity in breast cancer. Adv Exp Med Biol 1152: 31-49, 2019.

14. Barcenas CH, Wells J, Chong D, French J, Looney SW and Samuel TA: Race as an independent risk factor for breast cancer survival: Breast cancer outcomes from the medical college of Georgia tumor registry. Clin Breast Cancer 10: 59-63, 2010.

15. Wieder R, Shafiq B and Adam N: African American race is an independent risk factor in survival from initially diagnosed localized breast cancer. J Cancer 7: 1587-1598, 2016.

16. Taheri M, Tavakol M, Akbari ME, Anoshirvani AA, Aghabozorgi R,Almasi-Hashiani A and Abbasi M: Socioeconomic inequalities in metastasis, recurrence, stage and grade of breast cancer: A hospital-based retrospective cohort study. J Prev Med Hyg 60: E262-E269, 2019.

17. Beral V, Bull D, Doll R, Peto R and Reeves G: Breast cancer and breastfeeding: Collaborative reanalysis of individual data from 47 epidemiological studies in 30 countries, including 50 302 women with breast cancer and 96973 women without the disease. Lancet 360: 187-195, 2002.

18. Johansson H, Bonanni B, Gandini S, Guerrieri-Gonzaga A, Cazzaniga M, Serrano D, Macis D, Puccio A, Sandri MT, Gulisano M, et al: Circulating hormones and breast cancer risk in premenopausal women: A randomized trial of low-dose tamoxifen and fenretinide. Breast Cancer Res Treat 142: 569-578, 2013.
19. Dall GV and Britt KL: Estrogen effects on the mammary gland in early and late life and breast cancer risk. Front Oncol 7: 110, 2017.

20. Kröz M, Reif M, Glinz A, Berger B, Nikolaou A, Zerm R, Brinkhaus B, Girke M, Büssing A and Gutenbrunner C; CRF-2 study group: Impact of a combined multimodal-aerobic and multimodal intervention compared to standard aerobic treatment in breast cancer survivors with chronic cancer-related fatigue-results of a three-armed pragmatic trial in a comprehensive cohort design. BMC Cancer 17: 166, 2017.

21. Tsaras K, Papathanasiou IV, Mitsi D, Veneti A, Kelesi M, Zyga S and Fradelos EC: Assessment of depression and anxiety in breast cancer patients: Prevalence and associated factors. Asian Pacific J Cancer Prev 19: 1661-1669, 2018.

22. Fox RS, Ancoli-Israel S, Roesch SC, Merz EL, Mills SD, Wells KJ, Sadler GR and Malcarne VL: Sleep disturbance and cancer-related fatigue symptom cluster in breast cancer patients undergoing chemotherapy. Support Care Cancer 28: 845-855, 2020.

23. Costa C, Briguglio G, Giambò F, Catanoso R, Teodoro M, Caccamo D and Fenga C: Association between oxidative stress biomarkers and PON and GST polymorphisms as a predictor for susceptibility to the effects of pesticides. Int J Mol Med 45: 1951-1959, 2020

24. Costa C, Briguglio G, Catanoso R, Giambò F, Polito I, Teodoro M and Fenga $\mathrm{C}$ : New perspectives on cytokine pathways modulation by pesticide exposure. Curr Opin Toxicol 19: 99-104, 2020.

25. Giambò F, Teodoro $\mathrm{M}$, Costa $\mathrm{C}$ and Fenga C: Toxicology and microbiota: How do pesticides influence gut microbiota? A review. Int J Environ Res Public Health 18: 5510, 2021.

26. Giambò F, Italia S, Teodoro M, Briguglio G, Furnari N Catanoso R, Costa C and Fenga C: Influence of toxic metal exposure on the gut microbiota (Review). World Acad Sci J 3: 19, 2021.

27. Cohn BA, Cirillo PM and Terry MB: DDT and breast cancer: Prospective study of induction time and susceptibility windows. J Natl Cancer Inst 111: 803-810, 2019.

28. Darbre PD: Aluminium and the human breast. Morphologie 100: 65-74, 2016

29. Filippini T, Torres D, Lopes C, Carvalho C, Moreira P, Naska A, Kasdagli MI, Malavolti M, Orsini N and Vinceti M: Cadmium exposure and risk of breast cancer: A dose-response meta-analysis of cohort studies. Environ Int 142: 105879, 2020.

30. Hiatt RA and Brody JG: Environmental determinants of breast cancer. Annu Rev Public Health 39: 113-133, 2018.

31. Koual M, Tomkiewicz C, Cano-Sancho G, Antignac JP, Bats AS and Coumoul X: Environmental chemicals, breast cancer progression and drug resistance. Environ Health 19: 117, 2020.

32. Pullella K and Kotsopoulos J: Arsenic exposure and breast cancer risk: A re-evaluation of the literature. Nutrients 12: 3305, 2020.

33. Yang KJ, Lee J and Park HL: Organophosphate pesticide exposure and breast cancer risk: A rapid review of human, animal, and cell-based studies. Int J Environ Res Public Health 17: 5030, 2020.

34. Costa C, Miozzi E, Teodoro M and Fenga C: Influence of genetic polymorphism on pesticide-induced oxidative stress. Curr Opin Toxicol 13: 1-7, 2019.

35. Wegrzyn LR, Tamimi RM, Rosner BA, Brown SB, Stevens RG, Eliassen AH, Laden F, Willett WC, Hankinson SE and Schernhammer ES: Rotating night-shift work and the risk of breast Cancer in the nurses' health studies. Am J Epidemiol 186: 532-540, 2017.

36. Fagundo-Rivera J, Gómez-Salgado J, García-Iglesias JJ, Gómez-Salgado C, Camacho-Martín S and Ruiz-Frutos C: Relationship between night shifts and risk of breast cancer among nurses: A systematic review. Medicina (Kaunas) 56: 680, 2020.

37. Videnros C, Selander J, Wiebert P, Albin M, Plato N, Borgquist S, Manjer J and Gustavsson P: Postmenopausal breast cancer and occupational exposure to chemicals. Scand J Work Environ Heal 45: 642-650, 2019.

38. Gehlert S and Clanton M: Shift work and breast cancer. Int J Environ Res Public Health 17: 9544, 2020.

39. Lee DG, Burstyn I, Lai AS, Grundy A, Friesen MC, Aronson KJ and Spinelli JJ: Women's occupational exposure to polycyclic aromatic hydrocarbons and risk of breast cancer. Occup Environ Med 76: 22-29, 2019.

40. Schubauer-Berigan MK, Anderson JL, Hein MJ, Little MP, Sigurdson AJ and Pinkerton LE: Breast cancer incidence in a cohort of U.S. flight attendants. Am J Ind Med 58: 252-266, 2015. 
41. Costa C, Mondello S, Micali E, Indelicato G, Licciardello AA, Vitale E, Briguglio G, Teodoro M and Fenga C: Night shift work in resident physicians: Does it affect mood states and cognitive levels? J Affect Disord 272: 289-294, 2020.

42. Briguglio G, Teodoro M, Italia S, Verduci F, Pollicino M, Coco M, De Vita A, Micali E, Alibrandi A, Lembo G, et al: Salivary biomarkers and work-related stress in night shift workers. Int J Environ Res Public Health 18: 3184, 2021.

43. Jalilian H, Ziaei M, Weiderpass E, Rueegg CS, Khosravi Y and Kjaerheim K: Cancer incidence and mortality among firefighters. Int J Cancer 145: 2639-2646, 2019.

44. Labrèche F, Kim J, Song C, Pahwa M, Ge CB, Arrandale VH, McLeod CB, Peters CE, Lavoué J, Davies HW, et al: The current burden of cancer attributable to occupational exposures in Canada. Prev Med 122: 128-139, 2019.

45. Eurofond. European Working Conditions Survey, 3 Nov, 2020.

46. Szkiela M, Kusideł E, Makowiec-Dabrowska T and Kaleta D: Night shift work-A risk factor for breast cancer. Int J Environ Res Public Health 17: 659, 2020.

47. Gómez-Salgado J, Fagundo-Rivera J, Ortega-Moreno M, Allande-Cussó R, Ayuso-Murillo D and Ruiz-Frutos C: Night work and breast cancer risk in nurses: Multifactorial risk analysis. Cancers (Basel) 13: 1470, 2021.

48. IARC: IARC monographs on the evaluation of carcinogenic risks to humans. In: Vol. 93. IARC Monographs on the Evaluation of Carcinogenic Risks to Humans, pp9-38, 2010.

49. Bustamante-Montes LP, Flores-Meza B, Hernández-Valero MA, Cárdenas-López A, Dolores-Velázquez R, Borja-Bustamante P and Borja-Aburto VH: Night shift work and risk of breast cancer in women. Arch Med Res 50: 393-399, 2019.

50. Pahwa M, Labrèche F and Demers PA: Night shift work and breast cancer risk: What do the meta-analyses tell us? Scand J Work Environ Heal 44: 432-435, 2018

51. Xiang S, Dauchy RT, Hoffman AE, Pointer D, Frasch T, Blask DE and Hill SM: Epigenetic inhibition of the tumor suppressor ARHI by light at night-induced circadian melatonin disruption mediates STAT3-driven paclitaxel resistance in breast cancer. J Pineal Res 67: e12586, 2019.

52. Erdem JS, Notø HØ, Skare $\varnothing$, Lie JS, Petersen- Øverleir M, Reszka E, Pepłońska B and Zienolddiny S: Mechanisms of breast cancer risk in shift workers: Association of telomere shortening with the duration and intensity of night work. Cancer Med 6: 1988-1997, 2017

53. Erdem JS, Skare $\varnothing$, Petersen- $\varnothing$ verleir M, Notø HØ, Lie JS, Reszka E, Pepłońska B and Zienolddiny S: Mechanisms of breast cancer in shift workers: DNA methylation in five core circadian genes in nurses working night shifts. J Cancer 8: 2876-2884, 2017.

54. Cos S, Álvarez-García V, González A, Alonso CG and Martínez CC: Melatonin modulation of crosstalk among malignant epithelial, endothelial and adipose cells in breast cancer. Oncol Lett 8: 487-492, 2014

55. Touitou Y, Reinberg A and Touitou D: Association between ligh at night, melatonin secretion, sleep deprivation, and the internal clock: Health impacts and mechanisms of circadian disruption. Life Sci 173: 94-106, 2017.

56. Stevens RG and Schernhammer E: Epidemiology of uriniary melatonin in women and its relation to other hormones and night work. Cancer Epidemiol Biomarkers Prev 14: 551, 2005.

57. El-Benhawy SA, El-Tahan RA and Nakhla SF: Exposure to radiation during work shifts and working at night act as occupational stressors alter redox and inflammatory markers. Arch Med Res 52: 76-83, 2021.

58. Rosa D, Terzoni S, Dellafiore F and Destrebecq A: Systematic review of shift work and nurses' health. Occup Med (Lond) 69 237-243, 2019

59. Cordina-Duverger E, Menegaux F, Popa A, Rabstein S, Harth V, Pesch B, Brüning T, Fritschi L, Glass DC, Heyworth JS, et al: Night shift work and breast cancer: A pooled analysis of population-based case-control studies with complete work history. Eur J Epidemiol 33: 369-379, 2018

60. Sweeney MR, Sandler DP, Niehoff NM and White AJ: Shift work and working at night in relation to breast cancer incidence. Cancer Epidemiol Biomarkers Prev 29: 687-689, 2020.

61. Pahwa M, Labrèche F, Kim J, Harris MA, Song C, Peters CE, Arrandale VH, Davies H, McLeod CB and Demers PA: The impact of night shift work on breast cancer: Results from the burden of occupational cancer in Canada study. Am J Ind Med 62: 635-642, 2019.
62. Pham TT, Hwang M, Lee ES, Kong SY, Jung SY, Lee S, Kim J, Ha M, Kim SY and Park B: Night-shift work and risk of breast cancer in Korean women. Clin Epidemiol 11: 743-751, 2019.

63. Jones ME, Schoemaker MJ, McFadden EC, Wright LB, Johns LE and Swerdlow AJ: Night shift work and risk of breast cancer in women: The Generations Study cohort. Br J Cancer 121: 172-179, 2019.

64. Ritonja J, McIsaac MA, Sanders E, Kyba CCM, Grundy A, Cordina-Duverger E, Spinelli JJ and Aronson KJ: Outdoor light at night at residences and breast cancer risk in Canada. Eur J Epidemiol 35: 579-589, 2020.

65. Yang W, Shi Y, Ke X, Sun H, Guo J and Wang X: Long-term sleep habits and the risk of breast cancer among Chinese women: A case-control study. Eur J Cancer Prev 28: 323-329, 2019.

66. Garcia-Saenz A, Sánchez de Miguel A, Espinosa A, Valentin A, Aragonés N, Llorca J, Amiano P, Martín Sánchez V, Guevara M, Capelo R, et al: Evaluating the association between artificial light-at-night exposure and breast and prostate cancer risk in Spain (MCC-Spain study). Environ Health Perspect 126: 047011, 2018.

67. Lacerda JZ, Ferreira LC, Lopes BC, Aristizábal-Pachón AF, Bajgelman MC, Borin TF and de Campos Zuccari DAP: Therapeutic potential of melatonin in the regulation of MiR-148a-3p and angiogenic factors in breast Cancer. Microrna 8: 237-247, 2019.

68. Rajabi A, Saber A, Pourmahdi M, Emami A, Ravanbakhsh R, Khodavirdipour A, Khodaei M, Akbarzadeh M, Abdolahi S, Hosseinpourfeizi MA and Safaralizadeh R: Anti-cancer effect of melatonin via downregulation of Delta-like ligand 4 in Estrogen-responsive breast cancer cells. Recent Pat Anticancer Drug Discov 15: 329-340, 2020.

69. El-Sokkary GH, Ismail IA and Saber SH: Melatonin inhibits breast cancer cell invasion through modulating DJ-1/KLF17/ID-1 signaling pathway. J Cell Biochem 120: 3945-3957, 2019.

70. Liu P, Xie X, Yang A, Kong Y, Allen-Gipson D, Tian Z, Zhou L, Tang $\mathrm{H}$ and $\mathrm{Xie} \mathrm{X}$ : Melatonin regulates breast cancer progression by the lnc010561/miR-30/FKBP3 Axis. Mol Ther Nucleic Acids 19: 765-774, 2020.

71. Chuffa LGA, Carvalho RF, Justulin LA, Cury SS, Seiva FRF, Jardim-Perassi BV, Zuccari DAPC and Reiter RJ: A meta-analysis of microRNA networks regulated by melatonin in cancer: Portrait of potential candidates for breast cancer treatment. J Pineal Res 69: e12693, 2020.

72. Salamanca-Fernández E, Rodríguez-Barranco M, Guevara M, Ardanaz E, Olry de Labry Lima A and Sánchez MJ: Night-shift work and breast and prostate cancer risk: Updating the evidence from epidemiological studies. An Sist Sanit Navar 41: 211-226, 2018.

73. Dun A, Zhao X, Jin X, Wei T, Gao X, Wang Y and Hou H: Association between night-shift work and cancer risk: Updated systematic review and meta-analysis. Front Oncol 10: 1006, 2020.

74. Yuan X, Zhu C, Wang M, Mo F, Du W and Ma X: Night shift work increases the risks of multiple primary cancers in women: A systematic review and meta-analysis of 61 articles. Cancer Epidemiol Biomarkers Prev 27: 25-40, 2018.

75. Lee HE, Lee J, Jang TW, Kim IA, Park J and Song J: The relationship between night work and breast cancer. Ann Occup Environ Med 30: 11, 2018

76. Zhou L, Chen X, Liu T, Gong Y, Chen S, Pan G, Cui W, Luo ZP, Pei M, Yang $\mathrm{H}$ and He F: Melatonin reverses $\mathrm{H} 2 \mathrm{O} 2$-induced premature senescence in mesenchymal stem cells via the SIRT1-dependent pathway. J Pineal Res 59: 190-205, 2015.

77. de Castro TB, Bordin-Junior NA, de Almeida EA and de Campos Zuccari DAP: Evaluation of melatonin and AFMK levels in women with breast cancer. Endocrine 62: 242-249, 2018

78. Samavat $\mathrm{H}$ and Kurzer MS: Estrogen metabolism and breast cancer. Cancer Lett 356: 231-243, 2015.

79. Costa G, Haus E and Stevens R: Shift work and cancer-Considerations on rationale, mechanisms, and epidemiology. Scand J Work Environ Heal 36: 163-179, 2010.

80. Everson CA, Henchen CJ, Szabo A and Hogg N: Cell injury and repair resulting from sleep loss and sleep recovery in laboratory rats. Sleep 37: 1929-1940, 2014.

81. Davies SK, Ang JE, Revell VL, Holmes B, Mann A, Robertson FP, Cui N, Middleton B, Ackermann K, Kayser M, et al: Effect of sleep deprivation on the human metabolome. Proc Natl Acad Sci USA 111: 10761-10766, 2014.

82. Vaughn CB, Freudenheim JL, Nie J, Sucheston-Campbell L, Wactawski-Wende J, Marian C, Shields PG, Kallakury BV, Trevisan $\mathrm{M}$ and Ochs-Balcom HM: Sleep and breast cancer in the western New York exposures and breast cancer (WEB) study. J Clin Sleep Med 14: 81-86, 2018. 
83. McNeil J, Heer E, Willemsen RF, Friedenreich CM and Brenner DR: The effects of shift work and sleep duration on cancer incidence in Alberta's Tomorrow Project cohort. Cancer Epidemiol 67: 101729, 2020.

84. Shostak A: Circadian clock, cell division, and cancer: From molecules to organism. Int J Mol Sci 18: 873, 2017.

85. Hernández-Rosas F, López-Rosas CA and Saavedra-Vélez MV: Disruption of the molecular circadian clock and cancer: An Epigenetic Link. Biochem Genet 58: 189-209, 2020.

86. Sahar S and Sassone-Corsi P: Circadian clock and breast cancer: A molecular link. Cell Cycle 6: 1329-1331, 2007.

87. Xia L, Ma S, Zhang Y, Wang T, Zhou M, Wang Z and Zhang J: Daily variation in global and local DNA methylation in mouse livers. PLoS One 10: e0118101, 2015.

88. Shi F, Chen X, Fu A, Hansen J, Stevens R, Tjonneland A, Vogel UB, Zheng T and Zhu Y: Aberrant DNA methylation of miR-219 promoter in long-term night shiftworkers. Environ Mol Mutagen 54: 406-413, 2013.

89. Kochan DZ, Ilnytskyy Y, Golubov A, Deibel SH, McDonald RJ and Kovalchuk O: Circadian disruption-induced microRNAome deregulation in rat mammary gland tissues. Oncoscience 2: 428, 2015.

90. Pham TT, Lee ES, Kong SY, Kim J, Kim SY, Joo J, Yoon KA and Park B: Night-shift work, circadian and melatonin pathway related genes and their interaction on breast cancer risk: Evidence from a case-control study in Korean women. Sci Rep 9: 10982. 2019.

91. Carugno M, Maggioni C, Crespi E, Bonzini M, Cuocina S Dioni L, Tarantini L, Consonni D, Ferrari L and Pesatori AC: Night shift work, DNA methylation and telomere length: An investigation on hospital female nurses. Int J Environ Res Public Health 16: 2292, 2019.

92. Bracci M, Ciarapica V, Zabaleta ME, Tartaglione MF, Pirozzi S, Giuliani L, Piva F, Valentino M, Ledda C, Rapisarda V, et al: BRCA1 and BRCA2 gene expression: Diurnal variability and influence of shift work. Cancers (Basel) 11: 1146, 2019.
93. Hadadi E, Taylor W, Li XM, Aslan Y, Villote M, Rivière J Duvallet G, Auriau C, Dulong S, Raymond-Letron I, et al: Chronic circadian disruption modulates breast cancer stemness and immune microenvironment to drive metastasis in mice. Nat Commun 11: 3193, 2020.

94. Montagnese C, Porciello G, Vitale S, Palumbo E, Crispo A, Grimaldi M, Calabrese I, Pica R, Prete M, Falzone L, et al: Quality of life in women diagnosed with breast cancer after a 12-month treatment of lifestyle modifications. Nutrients 13: 136 , 2020.

95. Porciello G, Montagnese C, Crispo A, Grimaldi M, Libra M, Vitale S, Palumbo E, Pica R, Calabrese I, Cubisino S, et al: Mediterranean diet and quality of life in women treated for breast cancer: A baseline analysis of DEDiCa multicentre trial. PLoS One 15: e0239803, 2020.

96. Briguglio G, Costa C, Pollicino M, Giambò F, Catania S and Fenga C: Polyphenols in cancer prevention: New insights (Review). Int J Funct Nutr 1: 9, 2020.

97. Falzone L, Grimaldi M, Celentano E, Augustin LS and Libra M: Identification of modulated micrornas associated with breast cancer, diet, and physical activity. Cancers (Basel) 12: 2555, 2020.

98. Montagnese C, Porciello G, Vitale S, Palumbo E, Crispo A, Grimaldi M, Calabrese I, Pica R, Prete M, Falzone L, et al: Quality of life in women diagnosed with breast cancer after a 12-month treatment of lifestyle modifications. Nutrients 13: 136, 2020.

99. Leensen MC, Groeneveld IF, van der Heide I, Rejda T, van Veldhoven PLJ, Berkel SV, Snoek A, Harten WV, FringsDresen MH and de Boer AG: Return to work of cancer patients after a multidisciplinary intervention including occupational counselling and physical exercise in cancer patients: A prospective study in the Netherlands. BMJ Open 7: e014746, 2017. 